Семененко В. М. к.т.н, с.н.с. (ORCID 0000-0001-5774-0868);

Антоненко С. I. (ORCID 0000-0002-0729-8431);

Мудрак Ю. М.

(ORCID 0000-0002-1159-5746)

Центр воєнно-стратегічних досліджень Національного університету оборони України імені Івана Черняховського, Київ

\title{
Аналіз проблем організації та проведення огляду спроможностей в Міністерстві оборони України та Збройних Силах України
}

Резюме. У статті здійснено аналіз проблем організації та проведення огляду спроможностей в Міністерстві оборони України та Збройних Силах України для формування спільного розуміння щодо підходів до його впровадження.

Ключові слова: аналіз; спроможності; сили оборони.

Постановка проблеми. Восннополітична обстановка довкола України (агресія Російської Федерації проти України, тимчасова окупація Автономної Республіки Крим, проведення операції об'єднаних сил на Сході України, нарощування військових угруповань біля наших кордонів, захоплення в полон українських військових моряків і суден у Керченській протоці) потребує ефективного проведення процедур оборонного планування в Міністерстві оборони України та Збройних Силах України.

Основним індикатором для розв'язання зазначеної проблеми має стати Стратегічний оборонний бюлетень України, який має розроблятися Міністерством оборони України після затвердження Стратегії воєнної безпеки України за результатами оборонного огляду [1].

Зазначена робота потребує грунтовного наукового дослідження та супроводження, оскільки порядок оборонного огляду Міністерством оборони, який затверджений Урядом [2], на практиці не апробований, так само, як і порядок огляду спроможностей.

Аналіз останніх досліджень і публікацій. Проблема організації та проведення огляду спроможностей розглядалась у наукових працях військових фахівців, зокрема I. С. Руснака, М. М. Дєнєжкіна, П. М. Крикуна, В. М. Можаровського та інших [3, 4]. Розглянуті у згаданих працях проблеми спонукають до певного вдосконалення нормативно-правових актів для наближення до стандартів армій держав-членів НАТО, що потребує відповідного фахового обговорення $\mathrm{i}$ дослідження.
Водночас, питання огляду спроможностей визначено не лише в Порядку проведення оборонного огляду Міністерством оборони [2], але і в Тимчасових рекомендаціях iз проведення огляду спроможностей за функціональними групами [5] та Рекомендаціях 3 оборонного планування на основі спроможностей в Міністерстві оборони України та Збройних Силах України” (далі Рекомендації) [6].

Метою статті $\epsilon$ обгрунтування рекомендацій щодо розв'язання проблем організації та проведення огляду спроможностей в Міністерстві оборони України та Збройних Силах України.

Викладення основного матеріалу. Огляд спроможностей здійснюється під час середньострокового оборонного планування (або за рішенням Міністра оборони України кожні два-три роки), як це визначено в Рекомендаціях [6, п. 5.11].

Під час огляду спроможностей органами військового управління стратегічного, оперативного, тактичного рівня, командирами, начальниками i керівниками структурних підрозділів і організацій здійснюється оцінювання наявних спроможностей (оперативних, бойових, спеціальних) (п. 7 Рекомендацій) для ефективного реагування на спектр сучасних та майбутніх викликів і загроз воєнного (гібридного) характеру.

За результатами огляду спроможностей розробляється Стратегічна оборонна директива 3 питань реалізації держаної політики у сфері оборони у Збройних Силах України та інших складових сил оборони (п. 5.13 Рекомендацій), також може уточнюватись Комплексний документ 3 розвитку спроможностей Збройних Сил України (п. 5.14 Рекомендацій) [6]. 
Порядок організації та проведення огляду спроможностей потребує визначення й опису в чинних нормативних документах. 3 досвіду США та інших країни НАТО, огляд спроможностей в Україні доцільно проводити за процедурами оцінювання на основі спроможностей, основними складовими якого має бути визначення вимог до спроможностей, ідентифікація недоліків/проблем у досягненні необхідних 3 них та надання рекомендацій для досягнення визначених спроможностей відповідно до базових елементів (DOTMLPFIP) [7].

Відповідно до Рекомендацій 3
оборонного планування на основі
спроможності в Міністерстві оборони України та Збройних Силах України огляд спроможностей здійснюється відповідними органами військового управління під час оборонного огляду або окремо.

Для виключення суб'єктивізму під час проведення огляду спроможностей i наукового обгрунтування його результатів доцільно використовувати методики та інструменти стратегічного аналізу, а саме: метод експертних оцінок Дельфі (Delphi technique); методику комплексного аналізу (PEST analysis: political, economic, sociocultural and technological); методику аналізу сильних i слабких сторін, можливостей i загроз (SWOT: strengths, weaknesses, opportunities and threats analysis), методику аналізування прогалин (Gap Analysis), методику профілювання ризиків (Risk Profiling) тощо.

$$
\text { Базові елементи (складові) }
$$

спроможностей включають:

доктринальну складову, що передбачає наявність стратегій, концепцій, настанов, інструкцій, доктрини застосування сил оборони, стандартних операційних процедур та інших керівних документів щодо розвитку спроможностей складових сил оборони, їх застосування/діяльності;

організаційну складову, яка передбачає наявність певних структур складових сил оборони або їх сил і засобів, які створюють відповідні спроможності;

підготовку, яка об'єднує в єдину систему підготовки сил оборони, індивідуальну і колективну підготовку особового складу, підготовку штабів i військових формувань складових сил оборони. Це забезпечує створення спроможностей щодо рівня підготовки сил оборони;

ресурсне забезпечення, яке передбачає забезпеченість необхідним озброєнням i військовою технікою, обладнанням, запасами матеріально-технічних засобів і витратних матеріалів, фінансовими, інформаційними та іншими ресурсами;

якість управління та освіту, що полягає в досягненні необхідного рівня професійної підготовки керівного складу, органів військового управління усіх ланок, системи військової освіти та науки, який забезпечив би управління міжвидовими та міжвідомчими угрупованням військ (сил) під час їх застосування, а також сталий розвиток складових сил оборони;

персонал, що означає наявність кваліфікованого та мотивованого особового складу;

військову інфраструктуру, яка включає сукупність об'єктів і окремих споруд різного призначення для розквартирування військ (сил) у місцях постійної дислокації, розміщення на полігонах і в районах виконання оперативних завдань тощо;

сумісність, що передбачає доктринальну, оперативну та технічну сумісність сил і засобів для спільних дій у складі міжвидових $\mathrm{i}$ міжвідомчих угруповань військ (сил).

У процесі підготовки до огляду спроможностей необхідно визначити потребу у проведенні їхнього оцінювання, яке включає:

висвітлення нових викликів, які визначатимуть потребу в змінах або удосконаленні через процес оцінювання відповідних спроможностей складових сил оборони;

опис того, як спроможність була розвинута та застосована в нинішньому стані структурної побудови складових сил оборони;

обгрунтування потреб для

спроможностей, які визначаються, зважаючи на рівень загроз в нинішньому та майбутньому середовищі безпеки;

опис спроможностей у контексті бажаного кінцевого стану, шляхів досягнення поставлених цілей (виконаних заходів) і засобів щодо забезпечення виконання спроможностей; визначення та розроблення відомчих керівних документів щодо розвитку спроможностей тощо.

У рамках огляду спроможностей процес оцінювання спроможностей має включати такі аналітичні етапи:

відпрацювання Положення про операції об'єднаних сил, що визначає організаційні питання щодо створення робочих груп, визначення масштабів аналізу або обсягу напрямів діяльності об'єктів планування, 
затвердження програм/планів роботи на всіх аналітичних етапах тощо;

аналіз вимог, який включає виявлення вимог до спроможностей, конкретні завдання, умови, характеристики та показники результативності;

аналіз недоліків/проблем, що передбачає оцінювання необхідних спроможностей i визначення різниці між необхідними й наявними спроможностями, виявлення надлишкових/зайвих спроможностей;

аналіз рішень, а саме розроблення управлінських рішень щодо підтримки, нарощування, створення або позбавлення зайвих спроможностей складових сил оборони відповідно до базових елементів спроможності (DOTMLPFI-P);

розроблення документів, як заключний етап оцінювання, що передбачає підготовку загального звіту та розроблення Цільового пакету спроможностей сил оборони і планів розвитку спроможностей складових сил оборони, інших документів [7].

У Положенні про операції об'єднаних сил доцільно визначати основні функції суб' єктів планування складових сил оборони, систему управління процесами 3 досягнення поставлених цілей/очікувань, порядок узгодження дій учасників дослідження та проведення заходів певною методикою, окреслити/визначити бажані/очікувані результати досліджень, строки/терміни отримання i узагальнення результативних інформаційно-аналітичних матеріалів, значущість кожної структури/організації в процесі оцінювання, ключові визначення, нові поняття та ідеї, а також припущення, які вважаються прийнятними у процесі оцінювання.

Цей документ має чітко відповідати на такі питання (вимоги):

зміст і мета оцінювання;

результати, яких необхідно досягти та термін їх досягнення;

відповідальні особи стосовно розгляду та схвалення рекомендацій;

роль кожної структури у процесі оцінювання (порядок наведення результатів);

порядок подолання непорозумінь між учасниками процесу оцінювання і їх рамкові повноваження;

методологія оцінювання на основі спроможностей, етапи виконання завдань, обгрунтовані заходи та очікувані результати;

визначення основних понять, нових термінів і припущень.
У Положенні визначається i детальний підхід та часові рамки для оцінювання, висвітлюються ключові контрольні точки послідовної роботи учасників процесу оцінювання. Відповідно до контрольних точок визначається порядок наведення проміжних i кінцевих результатів (доповідей, звітів, документів тощо).

Аналіз вимог $\epsilon$ першочерговим аналітичним етапом оцінювання на основі спроможностей, який передбачає: формування вимог до спроможностей, які визначаються законодавчими актами, стратегічними, концептуальними, доктринальними й іншими документами у сфері безпеки та оборони; вивчення проблем досягнення визначених воєнно-політичних і воєнно-стратегічних цілей, шляхів і способів їх вирішення; формування комплексу заходів з розв'язання цих та інших проблем.

Таким чином, аналіз може об'єднувати процеси визначення:

концептуального бачення проблеми щодо формулювання та досягнення вимог до спроможностей (таке бачення може виконуватися за форматом: проблема, прогнозований кінцевий результат (ефект), шляхи досягнення результату, сплановані сили і засоби для забезпечення досягнення кінцевого результату);

переліку заходів, які необхідно виконати для забезпечення розвитку та функціонування спроможностей, або як реалізувати шляхи досягнення необхідних спроможностей, що визначаються під час розроблення концептуального бачення;

структур спроможностей (груп спроможностей), детального переліку завдань і підзавдань спроможностей, які визначені для оцінювання, кінцевих результатів, умов виконання тощо.

Слід зазначити, що для аналізу вимог вкрай важливим $\epsilon$ попередньо розроблений документ щодо опису майбутнього безпекового середовища навколо України, який містить результати оцінювання майбутнього безпекового середовища 3 перспективою не менш як на 10-15 років. Він є єдиним для всіх суб'єктів планування у сфері оборони, може використовуватися як вихідні дані для опрацювання Стратегії національної безпеки України, Стратегії воєнної безпеки України, доктрини застосування сил оборони, для розроблення сценаріїв, що використовуються для визначення та оцінювання необхідних спроможностей (груп спроможностей) тощо. 
Аналіз недоліків/проблем здійснюється за сферами впливу на спроможності, 3 урахуванням факторів впливу на формування проблем/недоліків та елементів, а також засобів їх визначення.

Недоліки можуть бути у трьох основних сферах впливу на спроможності:

контролюючі фактори, що регулюють процес виконання завдань - національне законодавство, політика оборонного планування, бюджетні кошти тощо;

вихідні ресурси, які необхідні для виконання завдання, зокрема особовий склад, матеріально-технічне та фінансове забезпечення сил оборони для підтримки сфери оборони;

механізми, що визначають структури (організаціі), які фактично виконують завдання, пов'язані зі спроможністю (вони складаються 3 персоналу, що складають організацію, процесів, які визначають спроможність та інструментів, що дають можливість виконати завдання).

Процес виявлення проблем/недоліків пов' язаний із:

спроможністю - до того ж оцінюється ступінь здатності або нездатності досягти необхідного ефекту у визначених умовах виконання завдань;

складом і чисельністю військ (сил) та обсягом ресурсів i можливістю або неможливістю їх задіяння для виконання визначених завдань;

строками експлуатації, які визначають: необхідність у заміні через старіння зразків OBT, матеріально-технічних та інших засобів; завершенням їх життєвого циклу та технологічне старіння тощо;

політичним обмеженням, яке пов'язано 3 неможливістю за потреби використати сили оборони через обмеження, що встановлені міжнародним правом або національним законодавством.

Під час визначення недоліків можуть використовуватися такі форми і способи: опитування шляхом безпосереднього спілкування, на основі таксономії, дистанційно у форматі аудиторного письмового опитування, через засоби зв'язку, телекомунікації в електронному форматі та іншими способами. До того ж для національного оборонного планування було б доцільним розроблення запитальників, що могло б сприяти усуненню непорозумінь та налагодженню ефективнішої взаємодії між суб' єктами планування; під час визначення недоліків комплексу дій у різних ситуаціях та умовах середовища безпеки передбачається розроблення сценарію;

інтерв'ю, яке можна провести у форматі співбесіди серед профільних спеціалістів або людей з відповідним досвідом тощо;

огляд літературних джерел, шляхом перегляду статей, вивчення документів, аналізу звітів про стан структур/організацій, які визначені для оцінювання;

узагальнення досвіду проведених операцій (бойових дій) у рамках проведення антитерористичної операції, операції об'єднаних сил, участі у операціях із підтримки миру i безпеки, підготовки військ (сил), висновки наукових досліджень у проведенні військових навчань тощо;

аналіз висновків старших командирів (керівників), які сфокусовані на визначенні та приорітезуванні проблем і недоліків.

За результатами аналізу недоліків/проблем розробляється відповідний звіт, який використовується, як основа для аналізу та прийняття рішень.

Аналіз рішення здійснюється відповідно до категорій базових елементів спроможностей (DOTMLPFI-P). У рішеннях доцільно вказувати організацію їх впровадження та очікуваний результат.

На основі аналізу рішень готуються рекомендації, які мають відповідати таким критеріям:

відповідність/придатність, що забезпечує мінімізацію або усунення недоліків або вирішення проблем;

реалістичність/доцільність, що визначає можливість реалізувати рекомендацію належним чином;

прийнятність, що забезпечує сприйняття цієї рекомендації всіма зацікавленими сторонами.

У цілому зазначені рекомендації щодо розв'язання проблем або усунення недоліків спрямовані на: підтримання наявних спроможностей; нарощування (удосконалення) базових компонентів (складових) спроможностей; формування нових спроможностей; позбавлення від надлишкових спроможностей.

Розроблення документів (рекомендацій), як результат аналізу рішень оформлюються у форматі звіту про розроблені проекти управлінських рішень, що надалі може бути підставою внесення їх у документи 3 розвитку спроможностей складових сил оборони. 
За результатами аналізу рішень доречно відпрацювати Імплементаиійний план, у якому мають міститися:

рекомендації, які $є$ специфічними та сфокусованими на одній проблемі/недоліку i оформлені, як правило, у форматі - одна проблема - одна рекомендація;

організація/структура, яка визначена відповідальною за впровадження (фінансування) рекомендацій;

терміни/строки або дата завершення виконання рекомендацій;

зв'язки, що визначає послідовність виконання (наприклад, політика оборонного планування має бути визначена перед відпрацюванням проекту доктрини i таке інше);

обсяг ресурсів для впровадження рекомендацій - якщо реалізація рекомендації потребує бюджетних видатків, то це має бути прописано у відповідних бюджетних програмах із визначенням виконавців за фінансування.

На заключному етапі оцінювання на основі спроможностей готується загальний звіт і розробляються документи розвитку спроможностей, зокрема Цільовий пакет спроможностей сил оборони та плани розвитку спроможностей складових сил оборони.

Важливо у процесі оцінювання на основі спроможностей ураховувати розподіл функцій і завдань, що покладаються на:

органи військового управління щодо оперативного планування, зокрема: створення планів застосування сил оборони для реалізації національних оборонних стратегій та реагування на воєнні загрози; проведення заходів зі стримування збройної агресії; здійснення управління силами оборони під час ïх застосування та розвитку тощо;

відповідні структурні підрозділи Міністерства оборони України та Генерального штабу Збройних Силах України щодо: комплектування особовим складом; матеріально-технічного забезпечення; оснащення (включно 3 науководослідницькою діяльністю); підготовки; технічного обслуговування; мобілізації та демобілізації; управління (у тому числі 3 питань соціальної підтримки та побутового забезпечення); планово-ремонтних робіт; розроблення, оснащення та ремонту військової техніки; будівництва, обслуговування та ремонт об' єктів військової інфраструктури; придбання нерухомого майна тощо.
Висновки. Таким чином, у статті проведено аналіз і надані рекомендації щодо розв'язання проблем організації та проведення огляду спроможностей в Міністерстві оборони України та Збройних Силах України. 3'ясовано, що лише за чіткого розподілу функцій, завдань, відповідальності та організації взаємодії всіх суб'єктів оборонного планування, їх органів під час виконання процедур і заходів планування залежатиме якість вихідних документів огляду спроможностей сил оборони.

У зв'язку із започаткуванням нового циклу оборонного планування вважається доцільним:

урахувати вимоги Закону України "Про національну безпеку України" від 21.06.2018 № 2469-VIII;

ініціювати проведення огляду спроможностей в найближчу перспективу;

у ході огляду спроможностей провести оцінювання спроможностей у Міністерстві оборони України та Збройних Силах України відповідно до Рекомендацій 3 порядку організації проведення оцінювання спроможностей у Збройних Силах України та "Рекомендацій 3 проведення огляду спроможностей сил оборони" у разі їх затвердження.

Напрям подальших досліджень. Для розв'язання зазначених проблем необхідно вдосконалити чинне законодавство сектору безпеки і оборони, визначити у ньому функції всіх складових сил оборони, порядок взаємодії та застосування у передбачених законом випадках, порядок планування й розвитку необхідних їм спроможностей (усіх складових компонентів) для забезпечення ефективнішого виконання покладених на Збройні Сили України та інші складові сил оборони завдань щодо оборони держави від агресора.

\section{ПЕРЕЛІК ВИКОРИСТАНОЇ ЛІТЕРАТУРИ}

1. Закон України "Про національну безпеку України” від 21.06.2018 року № 2469-VIII.

2. Порядок проведення оборонного огляду Міністерством оборони: затв. Постановою КМ України від 31.10.2018 р. № 941 .

3. Дєнєжкін М. М., К Крикун П. М., Руснак I. С. Проблеми проведення комплексного огляду сектора безпеки та оборони України: погляди на його організацію та вирішення завдань // Наука i оборона. 2014. № 4. С. 3-10.

4. Можаровський В. М. Оборонний огляд в Україні: результати і висновки // Наука і оборона. 2012. № 4. C. 3-11.

5. Тимчасовими рекомендаціями 3 проведення огляду спроможностей за функціональними групами спроможностей в Міністерстві оборони 
України, Збройних Силах України та інших складових сил оборони, затв. МО України 18.10.2018 року.

6. Рекомендації з оборонного планування на основі спроможностей в Міністерстві оборони України та Збройних Силах України: затв. МО України 12.06.2017 року.

7. Сектор безпеки i оборони України: теорія, стратегія, практика. Монографія /Саганюк Ф.В.,
Фролов В.С., Устименко О.В., Лобко М.М., Семененко В.М., Сурков О.О. та ін. К., 2017. 180 с. 8. Сектор безпеки і оборони України: стратегічне керівництво та військове управління. Монографія / Руснак І.С., Фролов В.С., Саганюк Ф.В., Пушняков А.С., Лобко М.М., Павленко В.І., Устименко О.В. К.: ЦЗ МО та ГШ ЗС України, 2018. 230 с.

Стаття надійшла до редакційної колегії 16.11.2018

Семененко В. М. к.т.н, с.н.с.;

Антоненко С. И.;

Мудрак Ю. М.

Центр военно-стратегических исследований Национального университета оборони Украины имени Ивана Черняховского, Киев

Анализ проблем организации и проведения смотра возможностей в Министерстве обороны Украины и Вооруженных Силах Украины

Резюме. В статье проведен анализ проблем организации и проведения смотра возможностей в Министерстве обороны Украины и Вооруженных Силах Украины с целью формирования общего понимания относительно подходов к его внедрению.

Ключевые слова: анализ; способности; силы обороны.

\section{Semenenko, PhD (Technical), senior researcher;}

\section{S. Antonenko;}

Y. Mudrak

Center for Military and Strategic Studies of the National Defence University of Ukraine named after Ivan Cherniakhovskyi, Kyiv

Analysis of the problems of organizing and conducting a review of opportunities in the Ministry of Defense of Ukraine and the Armed Forces of Ukraine

Resume. The article analyzes the problems of organizing and conducting a review of opportunities in the Ministry of Defense of Ukraine and the Armed Forces of Ukraine in order to form a common understanding regarding approaches to its implementation.

Keywords: analysis; abilities; defense forces. 